"Europeanization and Discourses of Globalization: Narratives of External Structural Context in the European Commission"

Ben Rosamond

CSGR Working Paper No. 51/00

May 2000
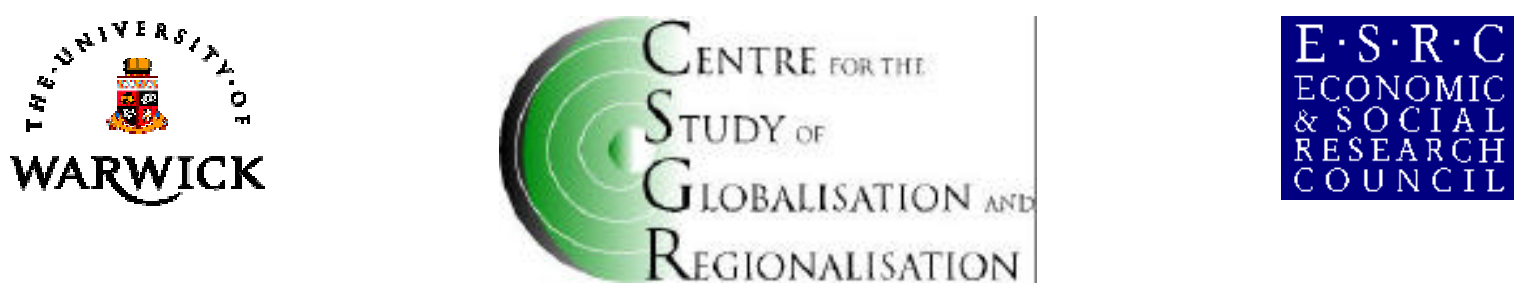

Centre for the Study of Globalisation and Regionalisation (CSGR), University of Warwick, Coventry CV4 7AL, United-Kingdom. URL: http://www.csgr.org 


\title{
Europeanization and Discourses of Globalization: Narratives of External Structural Context in the European Commission
}

Ben Rosamond ${ }^{1}$

CSGR, University of Warwick.

CSGR Working Paper No. 51/00

May 2000

\begin{abstract}
:
The growth of 'globalization studies' in the social sciences has done little to undermine the term's seemingly essential elasticity. Many academic debates about the veracity of the globalization hypothesis often struggle around meanings of 'globalization', yet the concept also possesses a 'real world' policy presence. There is evident need, therefore, for the more research on the development and uses of knowledge about globalization - to reflect, in other words, upon the subjective dimensions of processes that are said to be transforming the policy-making environment. This paper positions itself as a contribution to this academic manoeuvre and commences with a discussion of globalization as discourse and considers some problems for theory and method that follow. The second part of the argument offers some preliminary reflections on studying the European Commission as a venue for the discursive dimensions of globalization. The purpose of this discussion is (a) to map the development of ideas about globalization as used within the segmented policy-making structure of the Commission and (b) to dissect the forms of knowledge about 'globalization' that are present. In particular, the paper focuses on the distinct ways in which common narratives about a rapidly changing global context are used in terms of agenda setting. At the heart of the paper is the analysis of the proposition that discourses of globalization provide useful ideational ammunition for those seeking to legitimate moves towards European-level economic governance. The purpose of this discussion is (a) to map the development of ideas about globalization as used within the segmented policy-making structure of the Commission and (b) to dissect the forms of knowledge about 'globalization' that are present.
\end{abstract}

Keywords: Globalization, European Union, Discourse.

Address for correspondence:

Dr. Ben Rosamond

CSGR, University of Warwick

Coventry CV4 7AL, UK

Email: b.j.rosamond@warwick.ac.uk

\footnotetext{
${ }^{1}$ This paper is written with the support of the UK Economic and Social Research Council's 'One Europe or Several' Research Programme, award no. L213 252024 . This is a version of a paper presented to the UACES $30^{\text {th }}$ Anniversary and Fifth Research Conference, Central European University, Budapest, 6-8 April 2000. An earlier version was presented to the Annual Convention of the International Studies Association, Los Angeles, CA, March 14-18, 2000. Thanks to Bud Duvall, Willem Noe and Jeffrey Reznick for helpful comments and to Thomas Diez, Colin Hay and Jan Aart Scholte for constructive feedback on earlier work that feeds into the discussion here.
} 


\section{Introduction}

With globalization studies burgeoning, it is interesting to observe how often the concept is bemoaned for being imprecise, elastic, hyperbolic and confusing. Perhaps this general sense of unease has something to do with the fact that the concept of 'globalization' is not the sole property of the academy, but is alive in the 'real world' as a staple item of everyday discourse. 'Academic' concepts do not normally migrate easily into the vocabulary of everyday life. Thus there was a media outcry in Britain a few years ago when the (then) shadow chancellor Gordon Brown talked about 'endogenous growth theory' in a speech on economic policy. ${ }^{1}$ Yet no one raises an eyebrow when Brown or Tony Blair talk about 'globalization'. Thinking a little more analytically, students of International Relations have worked with the concept of 'anarchy' for many years. Yet anarchy is not a concept used especially in the world of international diplomacy or the public discourses that surround it. So we may be able to observe the social construction of international politics in ways that confirm the reproduction of something that

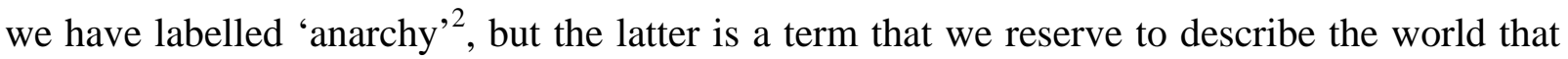
we investigate. The difference with globalization is that we (as recipients) know what this signifier means, but we (as scholars) are perhaps more confused. Globalization is everywhere or so we are told. And that is the problem!

This is why the study of discourses of globalization is so important. In a way this constitutes recognition that the power of globalization is derived precisely from its conceptual elasticity and under-specification. ${ }^{3}$ Also it is a conclusion that follows from the observation that the ways in which 'globalization' is used in the policy, journalistic and corporate communities often differs markedly from the nuanced understandings developed across a range of disciplines. ${ }^{4}$ At the same time though, many academic commentaries on globalization particularly in business studies, international economics and mainstream IPE - also appear to converge for the most part upon a common economistic conception of the term.

All of this raises many profound questions about, for example, the relationship between academic and other knowledges about globalization and indeed whether such a distinction is

\footnotetext{
${ }^{1}$ G. Brown MP, speech to the conference on 'New Policies for the Global Economy', 26 September 1994. On endogenous growth theory see N. Craft 'Post Neoclassical Endogenous Growth Theory', Oxford Review of Economic Policy 12(2), (1996). Thanks to Andrew Gamble and Colin Hay for guidance on this point.

${ }^{2}$ A. Wendt 'Anarchy is what states make of it: the social construction of power politics', International Organization 46(2), (1992)

${ }^{3}$ One analogy here might be ' the national interest'.
} 
valid. There are also interesting stories to uncover about the genealogy of globalization as a concept, how knowledge about globalization is acquired and dissipated, the ways in which it travels between distinct domains of human action and the power of particular understandings of the term. ${ }^{5}$

While locating itself within these broader questions, this paper has rather more modest and preliminary objectives. It begins by reflecting a little further on the treatment of globalization as discourse. Its empirical agenda is concerned with one particular site in which 'globalization' is the subject of intensive discursive practice - the European Commission. This part of the paper discusses some preliminary findings, but is really concerned with unbottling some issues that might inform further research.

\section{Globalization as discourse}

Globalization is normally construed in terms of an ongoing process that is impacting upon various aspects of human life or perhaps as a condition we have reached. In these senses globalization acquires the attributes of structure - something that contextualizes, enables or constrains human agency. Standard debates about globalization tend, therefore, to explore the veracity of the globalization hypothesis (i.e. whether globalization is happening and whether it is new). Is the world 'globalizing' or 'globalized'? Conclusions can then be drawn about the possibilities for action that seemingly follow. So if 'globalization' can be shown to be a myth, then claims about the limits of national governance and the futility of social democratic politics can be challenged. ${ }^{6}$ Such critiques draw momentum from the idea that the claims made about 'globalization' in certain strands of the literature or amongst certain political and corporate communities are highly exaggerated and, therefore, present a distorted picture of the realities of the contemporary international economy. But by implication efforts to disprove the globalization hypothesis contain a tacit acknowledgement that the concept of globalization has tremendous power. ${ }^{7}$ This is especially interesting because the idea that there is a single

\footnotetext{
${ }^{4}$ R. Robertson and H. Haque Khondker 'Discourses of Globalization: Preliminary Considerations', International Sociology 13(1), (1997); J.A. Scholte Globalization: A Critical Introduction (Basingstoke: Macmillan, 2000) ${ }^{5}$ The following have begun to touch on some of these questions: M. Low and C. Barnett 'After Globalisation', Society and Space 18, 2000; B. Rosamond 'Constructing Globalization’, in K. Fierke and K-E. Jørgensen (eds) Reconsidering Constructivism in International Relations (New York: M.E. Sharpe, 2000) - forthcoming; J.A. Scholte 'Beyond the Buzzword: Toward a Critical Theory of Globalization', in E. Kofman and G. Youngs Globalization: Theory and Practice (London: Pinter, 1996); Scholte Globalization; M. Waters Globalization (London: Routledge, 1995).

${ }^{6}$ P. Hirst and G. Thompson Globalization in Question (second edition) (Cambridge: Polity, 1999)

${ }^{7}$ In anticipation of the accusation that they are attacking a 'straw man', Hirst and Thompson claim to be taking on the 'most extreme version of the thesis on economic globalization' precisely because it has a coherence and
} 
'globalization hypothesis' in the academy is highly suspect. An inspection of the various strands of academic literature proves the point.

One apparently authoritative definition, drawn more or less at random from the voluminous literature, equates globalization with global integration, which in turn is defined as the process 'by which markets and production in different countries are becoming increasingly interdependent due to dynamics of trade in goods and services and the flows of capital and technology., ${ }^{8}$ This is a fairly typical definition of economic globalization, but as Smith, Solinger and Topik note, this can be broken down further into a series of sub-definitions covering phenomena such as the functional integration of national economies, the development of a new international division of labour, the emergence of global networks of production and the integration of financial markets. ${ }^{9}$

Another (rather more critical) source presents the following definition: '[Globalization] is a specific economic strategy pursued by the countries of the industrialised world and the transnational corporations (TNCs) whose interests they represent. ${ }^{10}$ The difference is subtle, but significant. The second definition talks about globalization as a particular form of corporate practice as well as the spread of that very practice across the world. ${ }^{11}$ It raises for us the question of whether globalization should be construed as a largely exogenous set of dynamics driven by the aggregation of world-wide market activity, or whether it is better thought of in terms of the interests and strategies of particular state and/or corporate actors. Is globalization something that affects us, or is globalization some thing that we do?

Therefore, it is not just that globalization has gained widespread acceptance as the defining environmental feature of the contemporary political economy. It is also the case that the instinctive understanding is of a global economic process bound up with changing patterns of corporate activity, international capital mobility and the spread of neo-liberal practices and policy discipline. Moreover, in seemingly dominant understandings of the term, it is a process

pervasivess as a set of claims about the economy that in turn has political consequences. See Globalization in Question (first edition) (Cambridge: Polity, 1996), pp.3-4.

${ }^{8}$ OECD Intra-Firm Trade (Paris: OECD, 1993), p.7

${ }^{9}$ D.A. Smith, D.J. Solinger and S.C. Topik 'Introduction', in D.A. Smith, D.J. Solinger and S.C. Topik (eds)

States and Sovereignty in the Global Economy (London: Routledge, 1999)

${ }^{10} \mathrm{http}$ ://www.oneworld.org/guides/globalisation/index.html (emphasis added)

11 See also D.S. Steingard, D.E. Fitzgibbons. 'Challenging the juggernaut of globalization: a manifesto for academic praxis'. Journal of Organizational Change Management 8(4), 1995. 
that imposes a 'logic of no alternative" ${ }^{12}$ and thereby presents agency - other than that which is itself engaged in globalizing ${ }^{13}$-as subject to the imperatives set by global forces. ${ }^{14}$

Of course, the thrust of most work on globalization concentrates on either (a) the veracity of 'the' globalization hypothesis or (b) work that follows from the tacit acceptance that globalization is happening or has happened. Without denigrating any of that work, the case for studying the language or the discourse(s) of globalization is relatively self-evident. Roland Robertson's seminal work thinks about the issue in terms of two dimensions: a 'world in itself' and a 'world for itself'. ${ }^{15}$ The latter suggests that the key to understanding the significance of globalization is that there is widespread consciousness and understanding of the world as a single place. The subjectivities of globalization are equally (if not more) important than its objective measurement. Thus, Malcolm Waters defines globalization as '[a] social process in which the constraints of geography on social and cultural arrangements recede and in which people become increasingly aware that they are receding. ${ }^{16}$

The purpose of this paper, and the research that informs it, is to think a little more coherently about the subjective side of 'globalization'. If in part globalization matters because there is widespread agreement that it matters, then some very serious issues of power, knowledge and strategy are at stake.

Jan Aart Scholte observes that control over knowledge about globalization is a high stakes issue: '[k]nowledge is power, and intellectual constructions of globalization help to shape the course of the trend. ${ }^{17}$ It should not earth-shattering news to hear that the way in which we conceive the world is not benign ${ }^{18}$ and Scholte's point is to lay the intellectual base camp for the development of critical theories of globalization. Critical theory, in this sense, is about both elaborating the conditions for emancipation and thinking critically about dominant bodies of knowledge and how they come to be hegemonic. It takes Robert Cox's well known point that

\footnotetext{
${ }^{12}$ C. Hay and M. Watson 'The Discourse of Globalisation and the Logic of No Alternative: Rendering the Contingent Necessary in the Downsizing of New Labour's Aspirations for Government', University of Birmingham, Department of Political Science and International Studies, mimeo (1999).

${ }^{13}$ See, for example, the speeches of former European Commission Vice-president Leon Brittan to see this paradox discussed in political rhetoric.

${ }^{14}$ For a thoughtful discussion and justification of the intellectual focus on economic globalization see G.

Thompson 'Situating Globalization', International Social Science Journal 160, June, 1999.

${ }^{15}$ R. Robertson Globalization: Social Theory and Global Culture (London: Sage, 1992)

${ }^{16}$ Waters Globalization, p. 3.

${ }^{17}$ Scholte 'Beyond the Buzzword', p.49
} 
theory is always for some one and for some purpose. ${ }^{19}$ It follows, therefore, that 'knowledgeable' accounts of the world are essentially political constructions. Crudely they may benefit particular interests or more subtly they may be bound up with the construction of certain interests in the global political economy.

The power of particular conceptions of globalization has a lot to do with the bundle of issues that the term signifies. To simplify, conceptions of globalization carry with them not just understandings of what the world is like, but also what can be done. Globalization has clearly become a site of political contestation. For example, Mark Rupert notes how the hegemonic liberal narrative of globalization is being increasingly challenged by (a) a cosmopolitan progressive leftism and (b) a recidivist autarchic conservatism. ${ }^{20}$

This also alerts us to the significance of academic debates about globalization. As suggested above, at one level they are about veracity, objectivity and situating globalization historically. At another level, they are struggle over the meaning of the term and thus the implications for structure and agency that follow.

A couple of recent examples should help to underline this point. One of the most significant and discussed books on globalization has been Paul Hirst and Grahame Thompson's Globalization in Question. ${ }^{21}$ The book is most notable for its overall scepticism about the claims made by the strong, 'borderless world' globalization hypothesis. ${ }^{22}$ With their redefinition of the world economy as internationalized rather than globalized, Hirst and Thompson are able to reinstate the case for (social democratic) national political agency as decidedly possible, even within a relatively fluid and turbulent economic environment.

Interestingly, Susan Strange argued that Hirst and Thompson's 'no change' thesis - by far and away the most publicised conclusion of the book - actually feeds the interests of corporate

\footnotetext{
${ }^{18}$ See G. Youngs International Relations in a Global Age: A Conceptual Challenge (Cambridge: Polity, 1999) for a discussion of the relationship between theoretical. discourses and the reproduction of the world

${ }^{19}$ R.W. Cox 'Social Forces, States and World Orders: Beyond International Relations Theory', Millennium: Journal of International Studies 10(2), 1981.

${ }^{20}$ M. Rupert 'Globalization and Contested Common Sense in the United States', in S. Gill and J.H. Mittelman (eds) Innovation and Transformation in International Studies (Cambridge: Cambridge University Press). See the virtual tour of rightist anti-globalism compiled by Mark Rupert at http://webdev.maxwell.syr.edu/merupert/Research/far-right/far_right.htm

${ }^{21}$ Op cit

${ }^{22}$ For a good discussion of the various types and intensities of hypotheses about globalization, see D. Held, A. McGrew, D. Goldblatt and J. Perraton Global Transformations: Politics, Economics and Culture (Cambridge: Polity, 1999).
} 
globalizers, neoliberal ideologues and advocates of deregulation and privatization. ${ }^{23}$ Thus their effort to mark out a space for the continuing practice of social democratic politics has perhaps downgraded the incentives for radical policy renewal. Also fascinating is Strange's intimation that the 'no change' argument is but one component of a more sophisticated thesis and that the authors themselves, plus their reviewers, may have simplified a somewhat more nuanced analysis in favour of a headline grabbing 'globalization as myth' soundbite.

A similar type of dispute arises in a recent exchange in the pages of the Review of International Political Economy between Colin Hay and Geoffrey Garrett. ${ }^{24}$ In a closely argued recent book, ${ }^{25}$ Garrett argues that globalization does not simply reward regimes that seek recourse to neo-liberal discipline. Indeed countries with strong social democratic/corporatist institutions can remain robust under conditions of globalization. Thus the logic and necessity of partisan politics has not been eradicated by the imperatives of globalization. The thrust of Hay's reading is that Garrett replaces a singular logic of no alternative with a bifurcated account of the inevitabilities associated with globalization. To recapture the social democratic imagination, he argues, it is necessary to challenge the mythology of globalization's logic of inevitability: 'Garrett's analysis may serve to shovel further soil over the coffin [of partisan politics], summoning as it does and institutionally mediated economic determinism in place of a simple economic determinism' ${ }^{26}$

These debates are not just about academic backbiting and certainly their development and resolution calls for serious evidence to be assembled to discuss globalization. The most obvious issue at stake in the two examples discussed above is how best to engage in the progressive governance of globalisation. But there is a second issue below the surface which is about how to engage in what might be termed the 'intellectual governance' of globalization discourse.

On the face of it, there is a relationship between the 'economistic' conceptions of 'globalization' found in corporate, journalistic and policy circles and the dominant ways in

\footnotetext{
${ }^{23}$ S. Strange 'Globalony?', Review of International Political Economy 5(4), 1998 p. 708. She argues that the data selected to show the reproduction of patterns in the international economy over time draws on dubious and difficult to verify sources, some of which have been misunderstood.

${ }^{24} \mathrm{C}$. Hay 'Globalization, social democracy and the persistence of partisan politics: a commentary on Garrett, Review of International Political Economy 7(1) (2000); G. Garrett 'Capital mobility, exchange rates and fiscal policy in the global economy', Review of International Political Economy 7(1) (2000).

${ }^{25}$ G. Garrett Partisan Politics in the Global Economy (Cambridge: Cambridge University Press, 1999)
} 
which it is thought of in the academy The point is not lost on some sociologists who argue that longer-standing sociological conceptions of 'globalization' have been marginalized at the expense of largely unidimensional discussions of economic globalization ${ }^{27}$. This is not just a case of IPE, business studies and international economics taking a narrow focus, but rather a matter of these disciplines misunderstanding the complex and multiple logics of globalization. For instance, in one of the most notable sociological treatments of globalization, Arjun Appadurai presents an image of intersecting 'scapes' along which flow various cultural, economic and ideational artefacts. ${ }^{28}$ This induces, what he calls 'relations of disjuncture':

By this I mean that the paths or vectors taken by these various kinds of things have different speeds, different axes, different points of origin and termination, and different relationships to institutional structures in different regions, nations or societies. Further these disjunctures themselves precipitate various kinds of problems and frictions in different local situations. Indeed it is the disjunctures between the various vectors that characterize this world-in-motion that produces fundamental problems of livelihood, equity, suffering, justice and governance. ${ }^{29}$

The point to make here is that there are clear issues to do with the sociology of knowledge in the social sciences. ${ }^{30}$ At first sight this seems to be about the ways in which an arriviste idea of economic globalization has vulgarized discussion of globalization in the political sciences. Perhaps also it intimates that it is this kind of knowledge about globalization (i.e. defined economically as either process or strategy and bound up with neoliberalism, capital mobility and transnational production) that has been taken up by the policy world broadly defined. Yet it seems to be equally possible that the concept first arose in business circles where its connotation was, of course, inherently economic. ${ }^{31}$

A self-evident imperative is for more work to be done on these deep sociology of knowledge questions about 'globalization' given that there is so much at issue in the manufacture of knowledge about the concept.

\footnotetext{
${ }^{26}$ Hay 'Globalization', pp.139-140.

${ }^{27}$ Robertson and Haque Khondker 'Discourses of Globalization', op cit.

${ }^{28}$ A. Appadurai Modernity at Large: Cultural Dimensions of Globalization (Minneapolis: University of Minnesota Press)

${ }^{29}$ A. Appadurai 'Globalization and the Research Imagination', International Social Science Journal 160, June, 1999, pp. 230-231.

${ }^{30}$ See ibid. For a densely argued discussion of globalization in light of the disciplinary pathologies of International Relations, see J. MacLean 'Philosophical Roots of Globalization and Philosophical Routes to Globalization', in R. Germain (ed.) Globalization and its Critics: Perspectives from Political Economy (Basingstoke: Macmillan, 2000)

${ }^{31}$ I am grateful to Glenda Rosenthal for this thought. See Waters Globalization for a discussion of the entry of globalization into the corporate lexicon in the 1950s.
} 
An important question at this stage is what do we mean by 'discourse'. What some have called 'the chatter of globalization ${ }^{32}$ is indicative of the sheer prevalence of talk about globalization and the assertiveness and contestation that often accompanies such discussions. But the concept of discourse needs to acquire a rather more precise and circumscribed meaning in order to be useful. In discourse analysis - especially that influenced by Foucault - discourse refers, not just to language but

to a broader matrix of social practices that gives meaning to the way that people understand themselves and their behaviour. A discourse, in this sense, generates the categories of meaning by which reality can be understood and explained. More precisely, a discourse makes 'real' that which it prescribes as meaningful. ${ }^{33}$

This organization of meaning is an exercise in power that helps to validate particular knowledgeable conceptions of reality (at the expense of others) and thereby situates actors in relation both to one another and to their structural environment. ${ }^{34}$ The study of discourse in this sense is about understanding the way in which actors develop and draw upon interpretative schemes and shared worlds of meaning in the reproduction of discursive structures of signification and legitimation'. ${ }^{35}$ In other words, the analysis of discourse becomes the analysis of processes of social construction that define the context and possibilities for human action. The focus on discourse requires a concentration on knowledge, both in terms of the ways in which dominant forms of knowledge become hegemonic and the ways in which those forms of knowledge are used to create structures of signification and the rules of the possible that follow.

At the core of discourse analysis is a concern with power and its exercise. By placing emphasis upon structures of signification, dominant forms of knowledge and the world of discursive practice, the aim is to show that authority is not only exercised through material capability, but also through ideational means. It is one way of challenging crude rationalist reasoning that evaluates the capabilities of actors from an 'objective' reading off of their material conditions.

\footnotetext{
${ }^{32}$ M. Dorsey 'The Chatter of Globalization and Transnationalism', presented to 'Globalization from Below: Contingency, Conflict, Contestation in Historical Perspective', Duke University, NC, 6-8 February, 1998.

${ }^{33}$ J. George Discourses of Global Politics: A Critical (Re)introduction to International Relations (Boulder: Lynne Rienner, 1994), pp. 29-30.

${ }^{34}$ See also S. Bislev, H.K. Hansen and D. Salskov-Iverson 'Transnational Discourse Communities: Globalizing Public Management', $41^{\text {st }}$ Annual Convention of the International Studies Association, Los Angeles, CA, March 14-18, 2000, pp.4-5.

${ }^{35}$ V. Jabri Discourses on Violence: Conflict Analysis Reconsidered (Manchester: Manchester University Press, 1996), p. 94.
} 
But there are at least two pathways from this point. For simplification these might be called the 'strategic' and 'reflexive' pathways. The question here is whether actors knowingly and strategically seek to construct the world in ways consistent with their interests. Are they, in other words, exogenous to the discourse? Thus, in the strategic variant of globalization discourse, the argument would be that powerful actors use the powerful idea globalization's 'logic of no alternative' to advance their interested pursuit of neo-liberal policy logic. As Grahame Thompson puts it, the power of the 'strong globalization thesis...leads to overdiminished expectations of what can still be achieved and to a disarming attitude on the part of all those concerned with public policy'. ${ }^{36}$ So the invocation of powerful market forces, particularly those associated with mobile capital, is a way of showing how policy options are constrained. Thus Colin Hay and Matthew Watson's discussion of the UK's New Labour government ${ }^{37}$ finds frequent rhetorical recourse to claims about the new economic conditions supplied by a globalizing economy. This means that it is not possible to shift policy away from the economic priorities pursued by the previous Conservative government. Additionally (socially constructed) external economic imperatives make a return to core, 'old' Labour, social democratic politics impossible. The so-called 'Third Way' - an idea bound up the New Labour Project in Britain as well as that of the Social Democratic Government of Gerhard Schröder in Germany (where the functionally equivalent term is die Neue Mitte) - draws heavily on the imagery of a transformed global economy to argue for the occupancy of a new policy space that is neither traditionally social democratic nor conventionally market liberal. ${ }^{38}$ Similarly Stephen Gill writes about 'globalizing elites': 'a grouping of organic intellectuals and political leaders within what can be called the transnational fraction of the capitalist classes of the world. ${ }^{39}$ They aim to "make transnational capitalism a class "for itself" by theorizing world order and by synthesizing strategy. ${ }^{40}$ Globalizing elites occupy roles within strategic international institutions, governments, think tanks and the like. Together they constitute a transnational community seeking to exploit material advantages of those operating in an emergent transnational economic space. They promote regulatory frameworks (and forms of deregulation) suitable for the advancement of those interests via the powerful and austere

\footnotetext{
${ }^{36}$ Thompson 'Situating Globalization', p.151. See also P. Hirst 'The global economy - myths and realities', International Affairs 73(3), 1997.

${ }^{37}$ Hay and Watson 'The Discourse of Globalisation' (op cit)

${ }^{38}$ See the joint statement by Gerhard Schröder and Tony Blair 'Europe: The Third Way/Die Neue Mitte'. See also A. Giddens The Third Way and its Critics (Cambridge: Polity, 2000)

39 S. Gill 'Political Economy and Structural Change: globalizing elites and the emerging world order', in Y. Sakamoto (ed.) Global Transformation: Challenges to the State System (Tokyo: United Nations University Press, 1994), p.182

${ }^{40}$ ibid
} 
discourses of 'market efficiency, discipline and confidence, policy credibility and consistency viewed from the standpoint of new theories in neo-classical economics in a world of international capital mobility'. Gill labels this disciplinary manifesto a form of 'new constitutionalism' ${ }^{41}$

What unites these two accounts is an emphasis on the strategic relationship between interests, discourses and behaviour (and indeed the separation of these as distinct categories). Gill's globalizing elites seek to define a 'common sense' in relation to the global macro-economy from which certain policy inevitabilities follow. The analytical point is that the strategic deployment of these discourses matters, not simply because they mask real (radical) alternatives to disciplinary neoliberalism, but because they will help to contribute to a world fashioned in the image of those discourses.

This raises the second pathway for the study of globalization discourses, labelled here the 'reflexive pathway'. Here

$$
\begin{aligned}
& \text { the spread of the discourse itself alters the a priori ideas and perceptions which people have of the } \\
& \text { empirical phenomena which they encounter; in so doing, it engenders strategies and tactics which in } \\
& \text { turn may restructure the game itself. With the erosion of old axioms, what follows might be called } \\
& \text { paradigmatic selection. And in this process, the concept of globalization increasingly shapes the } \\
& \text { terms of the debate. }
\end{aligned}
$$

At one level, the deployment of discourses may serve particular identified ends and the long run aspiration of these ends may not involve neoliberal globalisation. But there is more to this argument than a quasi-historical institutionalist claim about unintended consequences (though that does have undoubted mileage). It is about the relationship between the way we describe the world and the world that we describe. The reflexive pathway invites us to think about how the spread of intersubjective understandings alters both cognitive and material reality (and indeed problematizes the separation of the cognitive ant the material). It may be that 'globalization is what we make of it', but not in the strategic way that Kathleen McNamara seems to deploy that phrase. ${ }^{43}$ Rather the social construction of market imperatives contributes to the realisation of those market imperatives and to the altered 'globalizing' behaviour of various actors.

\footnotetext{
${ }^{41}$ See also S. Gill 'Globalisation, Market Civilisation and Disciplinary Neolibralism', Millennium: Journal of International Studies 24(3), 1995

${ }^{42}$ P.G. Cerny (1995) 'Globalization and other stories: the search for a new paradigm in international relations', International Journal 51(4), 1995, p.620
} 


\section{The European Commission as a venue for discursive practice}

The European Commission is an unusual body. It was designed to be a largely technocratic institution, imparting a non-nationalistic, community-wide focus to policy-making in the precursors of the European Union. Its primary institutional purpose is to be the initiator of legislation (while working within the boundaries set by the treaties). This ascribes to the Commission an entrepreneurial role, but in terms of day to day practice the Commission Directorates General (DGs) and services are engaged in highly technical, regulatory issues, often in consultation with various client groups and knowledge suppliers. ${ }^{44}$

Recent scholarship had paid considerable attention to the nature of the Commission's agendasetting role. It is quite apparent that the Commission (or its component DGs) engage in periodic policy advocacy, especially through written texts such as Green and White Papers, communications to other institutions and through the speeches of leading members of the College of Commissioners. For some the high level of policy entrepreneurship (compared to the bureaucratic apparatuses of the member-states) has much to do with the rather fluid and loosely institutionalised qualities of the EU policy process. This very lack of structure and order creates both the need and the space for 'strategic theorizing' and enterprising policy innovation. $^{45}$

Michelle Cini's discussion identifies four conceptions of Commission interest that seem to be inscribed on its institutional purpose. It is, firstly the 'conscience' of the EU. Secondly, it possesses a teleological role as an advocate of European integration as a destination (rather than as an ongoing process). Thirdly, the Commission contains a set of specific sectoral interests that are embodied in its segmented DG structure. This creates the basis for a set of games internal to the Commission Finally, as a bureaucratic actor, the Commission has an inherent interest in preserving and advancing its own policy competence. ${ }^{46}$ In a way these four

\footnotetext{
${ }^{43} \mathrm{~K}$. McNamara 'Globalization is What We Make of It? the Social Construction of Market Imperatives', presented to the annual meeting of the American Political Science Association, 28-31 August 1991.

${ }^{44}$ For detailed information on the Commission see N. Nugent The Government and Politics of the European Union ( $4^{\text {th }}$ edition) (Basingstoke, Macmillan, 1999), ch. 6; M. Cini The European Commission: Leadership, organisation and culture in the EU administration (Manchester: Manchester University Press, 1996)

${ }^{45}$ B.G. Peters 'Agenda-Setting in the European Union', in J. Richardson (ed.) European Union: Politics and Policy-Making (London: Routledge, 1996), p.63

${ }^{46}$ Cini The European Commission, pp.16-17
} 
interests were embedded at the moment of institutional design and provide the parameters within which the Commission as an agent or a set of agents must operate. ${ }^{47}$

Given this institutional inscription, it is not surprising to find that the Commission engages in the (semi-public) justification of its actions. But as Thomas Diez notes in his discussion of discourse approaches to European integration policy in the member-states, these interventions (like most publicly authoritative utterances in Western societies) are rule-bound. Such rules 'define the kind of articulations that can legitimately be made, and the sort of relations that they may propose. On one level, they determine the overall argumentative structure of the articulations. On a more concrete level, they proscribe the kinds of relations that can possibly be drawn between various elements'. ${ }^{4}$

Various accounts have sought to characterise the nature of the Commission in this context. Most agree that the Commission has become a creative player. Its capacity to utilise expansive readings of the treaties to open up new areas of policy competence, its alliance-building interaction with other institutions such as the European Court of Justice and its development of strategic networks with various non-state actors have been labelled 'purposeful opportunism. ${ }^{49}$ Thomas Christiansen argues that the Commission has over time become a more sophisticated bureaucracy with a (rationalist?) stake in expanding its policy competence, while finding more sophisticated mechanisms for achieving that end. ${ }^{50}$ Helen Drake notices the key place of the Commission in lending legitimacy to the EU and 'Europeanization' more generally - a necessary function given the absence of formal statehood as the basis of a 'legitimizing myth'. ${ }^{51}$ Bryan Wendon has portrayed the Commission as an 'image-venue entrepreneur'. ${ }^{5}$

\footnotetext{
${ }^{47}$ For a historical institutionalist account of the EU, see P. Pierson 'The Path to European Integration: A Historical Institutionalist Analysis', in W. Sandholtz and A. Stone Sweet (eds) European Integration and Supranational Governance (Oxford: Oxford University Press, 1998)

${ }^{48}$ T. Diez 'European Studies Meets the Fourth Debate: The Study of Discourse and the Analysis of European Integration Policy', paper presented to the annual conference of the British International Studies Association, 2022 December 1999, p.9

${ }^{49}$ L. Cram 'The European Commission as a multi-organization: social policy and IT policy in the EU', Journal of European Public Policy 1(2), 1994. For some specific examples see M.G. Cowles 'Seizing the Agenda for the New Europe: the ERT and EC 1992', Journal of Common Market Studies 33(4), 1995; N. Fligstein and I. MaraDrita 'How to Make a Market: Reflections on the Attempt to Create a Single Market in the European Union', American Journal of Sociology **(*), 1996; W. Sandholtz 'The Emergence of a Supranational Telecommunications Regime', in . W. Sandholtz and A. Stone Sweet (eds) European Integration and Supranational Governance (Oxford: Oxford University Press, 1998).

${ }^{50}$ T. Christiansen 'A maturing bureaucracy? The role of the Commission in the policy process', in J. Richardson (ed.) European Union: Power and Policy-Making (London: Routledge, 1996)

${ }^{51}$ H. Drake 'The European Commission and the Politics of Legitimacy in the European Union', in N. Nugent (ed.) At the Heart of the Union: Studies of the European Commission (Basingstoke: Macmillan, 1997)
} 
This has two components. The first involves taking control over the prevailing image of a policy problem via the use of language, signs and forms of policy knowledge. The second aspect consists in the construction of particular venues for the deliberation of the particular policy problem. In the case of social policy, this involved (a) constructing a new definition of Community social policy capable of appealing to the 'social partners', (b) building alliances with disaffected national social groups (such as trade unions) and simultaneously (c) making available the European-level as a venue for communication and deliberation on social policy matters.

Claudio Radaelli's work on policy narratives and advocacy coalitions in EU taxation policy shows the Commission at the heart of a supranational coalition also involving 'experts' and corporate actors. Again, there is evidence of powerful narrative devices being used by senior Commission figures to reformulate notions of European-level taxation away from the traditional emphasis on dealing with tax distortions incurred by multinational corporations towards a more comprehensive approach placing fiscal matters at the heart of the single market programme. In addition, Radaelli notices rhetorical interventions that aim to re-invent the Commission as a forum for the elaboration of tax policy. ${ }^{53}$

This all suggests that the Commission has both an institutional purpose and a modus operandi that leads it into moments of institutional entrepreneurship. Moreover, it does not merely engage in the advocacy of policy innovation, but also intervenes discursively to (a) reconfigure conceptions of particular policy areas and (b) insert itself as the primary forum within the European policy process for discussions in those domains of activity. The examples of social policy and taxation are telling for two reasons. Firstly, in each case there have existed - and continue to be - very powerful understandings that such areas fell with the domain of nationlevel action. Fiscal policy is usually construed as an area of 'high politics' and domestically forged social policy compacts have been integral to the conduct of public policy in all European states for much of the twentieth century. Secondly, both areas were given EU-level expression, but in a highly circumscribed manner. Thus, the 'Europeanization' of these policy areas requires their discursive construction as legitimate areas of concern for EU governance.

\footnotetext{
${ }^{52}$ B. Wendon 'The Commission as image-venue entrepreneur in EU social policy', Journal of European Public Policy 5(2), 1998.

${ }^{53}$ C. Radaelli The Politics of Corporate Taxation in the European Union: Knowledge and International Policy Agendas (London: Routledge, 1997); C. Radaelli 'Where Does Power Come From? The Narrative of Tax Competition in the European Union', paper presented to the ECPR Joint sessions, University of Warwick, 23-28 March, 1998.
} 
This in turn seems to necessitate the development of narratives about altered circumstances and the need for new conceptions of 'what is' social or tax policy.

\section{The Commission and globalization: some preliminary remarks}

Studying discourses of globalization within the Commission has a slightly different flavour, even though some of the dynamics described above seem pertinent. The most obvious point to make here is that unlike the two examples discussed above, 'globalization' does not, of course, constitute a (formal) policy domain in its own right. There is no DG formally charged with the issue and globalization has potentially serious implications for all areas where policy competence is held at the EU level. This generates three expectations. The first is that 'globalization' might be invoked as part of an attempt to either claim the need for the involvement of the Commission or redefine the scope of a policy area. The second expectation is that understandings of 'globalization' might vary within the Commission structure. The third is that detailed research on the meaning, extent and implications of globalization does not go on within the Commission itself.

The preliminary evidence seems to confirm these broad expectations. ${ }^{54}$ The discussion of globalization seems - so far at least - to have been confined to instances of policy advocacy in speeches by senior Commissioners, in Green and White Papers and within specialised departments of the Commission such as the Forward Studies Unit (Cellule de Prospective). The appearance of 'globalization' in such public utterances is relatively recent, but at the same time seems to have been inserted into an established pattern of rhetorical practice. This involves making a linkage between 'external' economic conditions and the need to augment and give meaning to the European level of action. In turn doubt is cast upon the ability of national governance to deliver appropriate policies to meet these external conditions. Thus, 'Europeanization' (and by implication Commission involvement) can be justified with reference to the arrival of urgent external imperatives. In addition, the case is often made for this Europeanization to take a neoliberal, market-driven form.

So at one level, elements within the Commission have latched onto the power of 'globalization' as a signifier of dramatic changes that impact upon the European political economy. The invocation of the concept could, therefore, be read as a wholly strategic exercise

\footnotetext{
${ }^{54}$ B. Rosamond 'Discourses of Globalization and the Social Construction of European Identities', Journal of European Public Policy 6(4), 1999.
} 
designed to enhance Europeanization, the position of the Commission and the pursuit of neoliberal modes of economic governance. This could be accommodated within a traditional rationalist bureau-shaping model or within those strategic approaches to globalization discourse that emphasise the relationship between the deployment of the concept and the loss of confidence in and seriously reduced expectations of the capacities of government.

This obviously has some analytical mileage, but it still muddies the issue of the extent to which Commission actors knowingly engage in these acts of discursive construction which in turn represents avoidance of the issue of interests. To argue that actors are being strategic presumes that we can establish their interests as being exogenous to processes of (institutionalized) interaction and discourse construction. On the face of it, this is difficult in this example because of the packaging of three distinct preferences (Commission advancement, Europeanization and neoliberalism). Moreover the presumption of strategic rationality discourages deeper reflection on the ways in which globalization is used in the language games of policy initiation. To treat it as an instrumental device takes us away from useful questions about its status as knowledge, its (discursive) relationship to the social construction of 'Europe' and its differential usage within the Commission DGs and other Commission departments.

One important issue for deeper research concerns the 'knowledgeability' of Commission actors about globalization. The apparent absence of autonomous internal research on globalization suggests that the concept is more or less wholly imported. This in turn begs the questions of which understandings of globalization prevail and of whether the wider academic/policymaking emphasis on particular kinds of economic globalization is reproduced within the Commission. It also ducks wider issues to do with how actors are socialized away from previous modes of thinking about macroeconomic policy and how dominant understandings of external context become normalized in their perceptions.

In terms of knowledge, Commission usages of 'globalization' treat it exclusively as an economic phenomenon. A typical definition is of globalization as 'the process by which markets and production in different countries are becoming increasingly interdependent due to the dynamic trade in goods and services and flows of capital. ${ }^{55}$ It is, therefore, a feature of the

\footnotetext{
${ }^{55}$ Commission of the European Communities 'Annual Economic Report for 1997', European Economy No.63 (1997), p. **
} 
policy-making environment that has knock on effects for whole range of policy areas. In that respect it is often used as a signifier in Commission discourse and may constitute either a threat or an opportunity.

But, in some quarters globalization is also linked to a set of particular policy preferences, bound up with the spread of neoliberal practices and regulatory frameworks. This can be further attached to wider IPE and EU Studies debates about the relationship between regional integration and globalization. Crudely, is globalization something that the EU facilitates, resists or synthesizes? ${ }^{56}$ I have noted elsewhere ${ }^{57}$.the argumentative strategy of the former Commission Vice-President and trade Commissioner Leon Brittan which described economic globalization as amounting to a series of challenges set by liberalization, to which the only efficacious European response was liberalization. His successor as trade Commissioner Pascal Lamy uses much the same technique:

Globalisation, a key element of which is international commerce, facilitated by the liberalisation of trade and investment, is not a zero-sum game where some lose what the others gain. It is to my mind a win-win process, as post-war economic history shows. Europe has profited from it, and will continue to so, provided that it preserves its long term competitiveness, its capacity for innovation, and its social market economy...I know that part of public opinion in Europe focuses more on the risks than the benefits of globalisation. Such opinion is concerned about possible instability, aggression, loss of identity. I do not share these concerns, but we have to take on board these worries and seek to convince our fellow European citizens that the answers lie in the quality of our own internal policies and in progress towards multilateral rules. We must not allow globalisation to become an alibi, or to be seen as a malign influence. ${ }^{58}$

This speech is interesting, not only because it makes assertions about a coherent 'Europe' confronted by global challenges, but also because it confirms a definite move to recognise that various challenges to (economic) globalization have begun to manifest themselves in the European and global political economies. Indeed, towards the end of his tenure, Brittan was arguing regularly that the (Asian) financial crisis that commenced in 1997 was the consequence of not enough globalization rather than too much. ${ }^{59}$ So while it seems that there is something of an intersubjective consensus about the broad meaning of globalization, there is considerable variability over time in the way that it is deployed and used.

\footnotetext{
${ }^{56}$ B. Rosamond 'Globalisation and Europeanisation', Yearbook of European Studies/Annuaire d'Etudes Européennes - forthcoming, 2000.

${ }^{57}$ Rosamond 'Discourses of Globalization' op cit

${ }^{58}$ P. Lamy 'Globalisation: a win-win process', Brussels, 15 September 1999, http://europa.eu.int/trade/speeches articles/spla01en.htm

${ }^{59}$ L. Brittan 'The Challenges of the Global Economy for Europe', speech to the Vlerick Annual Alumni Meeting, Ghent, 1998.
} 
Moreover, there are subtle differences in the implications drawn about agency in the context of 'globalization'. In some ways, the Brittan-Lamy position represents an alignment of the EU or specifically DG1/DG (Trade) - with the forces of globalizing capitalism. In some ways it is an impeccably structurationist argument. 'Europe' through internal and external liberalization contributes to globalization which then presents Europeans with challenges, which are best met through continual acts of liberalizing agency. Close readings of the policy advocacy and scenario analysis of other DGs shows a rather different positioning of 'Europe' in light of 'globalization'. Discussions of renewable energy policy within DGXVIII presented globalization as a largely detrimental threat and in so doing depicted the European energy market and the actors therein as largely passive and disempowered. ${ }^{60}$ The social construction of globalization as external threat is bound up to the social construction of Europe as an empirically discernible field of action, but it follows that particular 'sub-connotations' of 'globalization' also imply different possibilities for 'European' agency.

The further implication is that there are significant divisions within the Commission - perhaps reflecting its segmented character $^{61}$ - on globalization. An initial reading is that those DGs traditionally understood to be working in the powerful economic domains (trade, monetary policy, the single market) are those most attached to a proactive neoliberal account of globalization, whereas those dealing with areas such as energy, industry, social policy, the environment and agriculture tend to take up a more reactive posture vis-à-vis globalization.

Interestingly enough, the question of agency and empowerment has been a central feature of much of the work of the Commission's Forward Studies Unit. Its function is described as 'futurological ${ }^{62}$ and aside from acting as a strategic think tank to be used by various DGs, it is completing a five year programme bringing together four lines of work: 'legitimising the European project; managing the dual socio-economic and geopolitical transition; restoring the cohesion of European societies; adapting the art of government. ${ }^{63}$ On the first of these,

\footnotetext{
${ }^{60}$ Rosamond 'Discourses of Globalization', p.663.

${ }^{61}$ Quite a lot of work on the Commission suggests that the individual DGs are relatively cohesive and culturally distinct entities, often utilising distinctive working and linguistic practices. See M. Cini 'Administrative Culture in the European Commission: the Cases of Competition and Environment', in N. Nugent (ed) At The Heart of the Union: Studies in the European Commission (Basingstoke: Macmillan, 1997); M. McDonald 'Identities in the European Commission', in N. Nugent (ed) At The Heart of the Union: Studies in the European Commission (Basingstoke: Macmillan, 1997).

${ }^{62}$ Forward Studies Unit 'Mission', http://europa.eu.int/comm/cdp/mission/index en.htm

${ }^{63}$ Forward Studies Unit 'Five-year work programme: four major challenges for 1995-2000', http://europa.eu.int/comm/cdp/programme/index_en.htm
} 
the globalisation of markets and the individualisation of behaviour, which typified the eighties and nineties, have led to the need for a cultural identity, a desire to belong to a community. This will have a variety of implications for the legitimisation of the European project: 'national identities' are of such long standing that the more recent 'European awareness' will tend to be more fragile; on the other hand, this awareness will be reinforced when confronted by the clear international challenges and the cultural singularities claimed by the major regions of the world. ${ }^{64}$

Globalization features heavily as a key theme of the Forward Studies Unit's output. ${ }^{65}$ It is defined as 'the steady increase in the cross-border flows of trade, investment and financial capital since World War II, and its more recent acceleration as far as the two latter are concerned. $^{, 66}$

But perhaps a more significant running theme of the Unit's work is its brief to identify 'shaping factors' and 'shaping actors'. The express aim here is to reinforce awareness amongst European actors (principally firms, but also public sector bodies) of their environment and the potential for action. As one particularly telling passage put it:

Once awareness has been achieved, how will actors in the public and private sectors respond to the new situation: will they remain passive and simply adapt, or will they actively seek impose their will, shaping the shaping factors after the event? ${ }^{67}$

There is, of course great difficulty in drawing conclusions about the influence of think tanks. It is obviously their raison d'être to be a decisive factor in altering the cognitive climate and in that sense the Forward Studies Unit's tendency to present its material in ways that potentially empower agency is very interesting. What this example reinforces is the pattern of discursive practice that links the social construction of Europe(s) with the social construction of the global context of those Europes.

\footnotetext{
${ }^{64}$ ibid

${ }^{65}$ See especially G. Bertrand, A.Michalski, Lucio R. Pench Scenarios Europe 2010: Five Possible Futures for Europe (European Commission. Forward Studies Unit Working Paper, July 1999)

${ }^{66}$ ibid, p. 99.

${ }^{67}$ A. Jacquemin and D. Wright (eds) The European Challenges Post-1992: Shaping Factors, Shaping Actors (Aldershot: Edward Elgar, 1993) p.xvi
} 


\section{Conclusions}

The study of globalization as discourse or as an intersubjective phenomenon is no longer a rarity, but deeper empirically based research is still very much in its infancy. Venues like the European Commission seem to be good sites for thinking about the discursive strategies of globalizing elites, the formation of discourse coalitions, the status of globalization as knowledge and the conceptions of structure, agency, constraint and opportunity held by the actors themselves. There is still some fuzziness about the extent to which globalization discourses are studied as acts of strategic manipulation or as reflexive encounters between structure and agency. It needs to be understood that these can lead in very different epistemological directions and, therefore, might not constitute propositions that could be tested against one another. On a broader terrain, this kind of work re-emphasizes the futility of drawing boundaries between inside and outside in the study of the EU. The recognition of the discursive aspects of globalization problematizes the idea that global structural change is simply something 'out there' embedded in the logic of markets, which in a sense probematizes one of the core assumptions of the dominant economic liberal narrative of globalization. 